\title{
Prognostic impact of cytoplasmatic EGFR upregulation in patients with oral squamous cell carcinoma: A pilot study
}

\author{
MATTHIAS KAPPLER ${ }^{1 *}$, KEVIN DAUTER $^{1 *}$, WALDEMAR REICH $^{1}$, DANIEL BETHMANN $^{2}$, MICHAEL SCHWABE $^{3}$, \\ SWETLANA ROT $^{1}$, CLAUDIA WICKENHAUSER ${ }^{2}$, BILAL AL-NAWAS $^{1,4}$ and ALEXANDER W. ECKERT ${ }^{1}$ \\ ${ }^{1}$ Department of Oral and Maxillofacial Plastic Surgery, Martin Luther University Halle-Wittenberg, D-06120 Halle (Saale); \\ ${ }^{2}$ Institute of Pathology, Martin Luther University Halle-Wittenberg, D-06110 Halle (Saale); \\ ${ }^{3}$ DRK Kliniken Berlin Westend, D-14050 Berlin, Germany
}

Received February 4, 2020; Accepted September 19, 2020

DOI: $10.3892 / \operatorname{mco} .2020 .2158$

\begin{abstract}
In various tumors, epidermal growth factor-receptor (EGFR) serves a role in tumorigenesis and has an impact on survival. Usually the EGF-receptor is located on the surface of the cell membrane and is involved in various signaling pathways. The dimerization of EGFR with other ErbB family proteins, such as HER2, is important for the tumor progression. Nevertheless, a second EGFR-associated signaling pathway appears to be important for tumor cells, which is cytoplasmic/nuclear EGFR. The present study examined the influence of membranous or cytoplasmic localized EGFR on the prognosis of patients with oral squamous cell carcinoma (OSCC). Slides from 45 OSCC tumor samples were stained against EGFR using immunohistochemistry and analysed by the Remmele score system. The association with histopathological parameters and survival data was analyzed. Cytoplasmatic EGFR localization was identified as an independent predictive biomarker for overall survival in the examined OSCC cohort according to multivariate Cox regression analysis. Positive cytoplasmatic EGFR staining was correlated with a higher risk of early death $(R R=3.0 ; P=0.035)$, while membranous EGFR localization did not affect patient
\end{abstract}

Correspondence to: Dr Matthias Kappler, Department of Oral and Maxillofacial Plastic Surgery, Martin Luther University Halle-Wittenberg, Ernst-Grube-Str. 40, D-06120 Halle (Saale), Germany

E-mail: matthias.kappler@uk-halle.de

Present address: ${ }^{4}$ Department of Oral and Maxillofacial Surgery, University Hospital Mainz, D-55131 Mainz, Germany

\section{${ }^{*}$ Contributed equally}

Abbreviations: EGFR, epidermal growth factor-receptor; OSCC, oral squamous cell carcinomas; RR, relative risk

Key words: OSCC, epidermal growth factor-receptor, survival, cytoplasmatic EGFR survival. To the best of our knowledge, the present study is the first study to demonstrate that cytoplasmatic-localized EGFR is an independent prognostic biomarker for the overall survival of patients with OSCC.

\section{Introduction}

Oral squamous cell carcinoma (OSCC) is responsible for 300,000 tumor cases per year $(2012 ; 2.1 \%$ of all cancer worldwide) and is a tumor entity that is one of the 10 most common types of cancers worldwide (1). The five-year survival rate has stagnated at around $40-50 \%$ (2). For this reason, new molecular prognostic markers are urgently required to better estimate the outcome of OSCC patients.

The epidermal growth factor receptor (EGFR) is a transmembrane receptor with tyrosine kinase activity and regulates cellular processes such as proliferation, metastasis, radio- and chemoresistance (3).

EGFR is known to be overexpressed in a large number of human tumors of epithelial origin (3) and is associated with the outcome of tumor patients (4). The role of EGFR in head and neck squamous cell carcinoma (HNSCC) was extensively studied and the negative prognostic impact of EGFR overexpression on local control and patient survival has been described. Therefore, various therapies against EGFR are routinely used for HNSCC patients (5).

However, the impact of the subcellular EGFR-distribution on the prognosis is controversially discussed, especially when data were derived from immunohistochemical analysis in different OSCC patient cohorts (5-7). A possible explanation for the contradictory data could be the different function of e.g. membrane or cytoplasmatic/nuclear localized EGFR.

Some authors have described that cytoplasmatic/nuclear localized EGFR might be associated with a higher proliferation rate in cancer cells $(8,9)$.

In addition, it was found that especially an increased level of nuclear EGFR was associated with a poor prognosis of cancer patients (10). A study examined the prognostic value of nuclear expression of EGFR in tumor samples of OSCC patients. The authors found a nuclear EGFR staining in 23 patients $(28 \%)$ but no correlation with clinicopathological factors or patient outcome (11). 
Another possible reason for the ambiguous prognostic influence of EGFR for OSCC patients could be the occurrence of alternative EGFR isoforms, which could induce different signal transduction pathways compared to full length EGFR (12,13).

Therefore, we investigated the level and the localization (membranous/cytoplasmatic) of EGFR protein in OSCC samples and their effects on patient's outcome.

\section{Materials and methods}

Tissue samples and histopathologic data. We examined 45 paraffin-embedded tumor samples from OSCC patients. All patients underwent surgery at the Department of Oral and Maxillofacial Plastic Surgery at the University of Halle-Wittenberg, Germany. The clinical and histomorphological parameters of the cohort of OSCC patients are listed in Table I. The mean age of the patients was 57 years. Twenty eight patients $(62 \%)$ died after an average of 16.1 months, and 17 OSCC patients $(38 \%)$ were still alive after an average of 60 months. The study was conducted in accordance with the Helsinki Declaration and approved by the Ethics Committee of the Medical Faculty of the University Halle-Wittenberg (ethic number 2017-81 issued on June 27th, 2017). The human tissue samples were collected between 1998 and 2002. All patients underwent surgery according standardized regimens and gave their written consent $(14,15)$.

Immunohistochemistry. The IHC staining procedure was applied as previously described (15). Sections $(4 \mu \mathrm{m})$ of paraffin-embedded tissues were heated to $56^{\circ} \mathrm{C}$. Briefly, the tumor slides were deparaffinized with xylol and transferred into a series of ethanol dilution. The EGFR antibody (D38B1) (Cell Signaling Technology Inc.), tested by us in a previous work $(13,16)$, and routinely established for IHC staining in the Institute of Pathology (DRK Kliniken Berlin Westend), was used. The antibody was diluted according to the manufactory specifications (1:50). The staining (labeled streptavidin-biotin method) was performed by using a standard protocol on a semiautomatic staining facility (Ventana BenchMark; Roche Diagnostics). After staining, the sections were counterstained with Mayer's hematoxylin. The staining protocol followed a standard protocol of the Institute of Pathology (DRK Kliniken Berlin Westend) which always include necessary controls (omitting of the primary antibody). The stained slides were evaluated by an experienced pathologist (MS) and reevaluated by C.W. and D.B. using the Remmele Score system and taking into account the location of staining (membranous or cytoplasmic) (17). In detail: First the percentage of positive cells was assigned as: $1-10 \%$ positive cells as a score 1 , $11-50 \%$ positive cells as a score $2 ; 51-80 \%$ positive cells as a score 3 or $>80 \%$ positive cells as a score 4 . Secondly, the staining intensity was scored as negative (1), moderate (2) or intense (3). Scores for the percentage of positive cells and scores for the expression intensities were multiplied to calculate the immunoreactive score [IRS according to Remmele and Stegner (17)]: 0-2, no staining; 3-4, weak staining; 6-8, moderate staining; 9-12, strong staining (15). The EGFR staining was classified as i) membEGFR ( $20 \%$ positive $9 / 45$, in detail $n=36$ negative, $n=2$ weak, $n=7$ moderate and $n=0$ strong staining), ii) cytoEGFR (55.5\% positive $25 / 45$, in detail $n=20$ negative, $n=12$ weak, $n=12$ moderate and $n=1$ strong staining). For survival analysis, the cohort of OSCC patients was separated into two groups according to the expression level of membranous or cytoplasmic EGFR as negative (IRS 0-2) vs. positive staining (IRS 3-12).

Statistical analysis. The Cox's regression hazard model and Kaplan-Meier analysis was used to estimate a correlation between EGFR protein level and overall survival or relapsefree survival of OSCC patients. The model was adjusted for the prognostic effects of covariates (clinical T-stage, $\mathrm{N}$-stage and grading of the tumor and the sex and age of the patients). Correlation analysis was performed using the Kruskal-Wallis test or the Spearman rank correlation test. A probability $(\mathrm{P})$ of $<0.05$ was defined as significant and the relative risk (RR) was calculated as well as the confidence interval (CI). The statistical analysis was performed using SPSS software version 25.0 (SPSS Inc.).

\section{Results}

Prognostic effect of membranous EGFR and cytoplasmatic EGFR on overall and relapse free survival. The EGFR staining i) membEGFR ii) cytoEGFR (Fig. 1) was separated into two groups [low vs. median/high level (please see Materials and methods)].

By Kaplan-Meier analysis, we found that patients with a positive cytoEGFR level died on average 13.5 months $(\mathrm{P}=0.03)$ earlier than patients with a negative cytoEGFR protein localization (Table I). The membEGFR level had no significant correlation with the prognosis in the Kaplan-Meier analysis (Table II).

In the univariate Cox's proportional hazard regression analysis a positive cytoEGFR staining showed a significant correlation with a worse prognosis of the patients $(\mathrm{RR}=2.3$; $\mathrm{P}=0.039$ ), while membEGFR do not correlate with the prognosis.

Furthermore, we also performed a multivariate Cox's proportional hazard regression analysis adjusted to the T-stage, $\mathrm{N}$-stage, grading, sex and age of the patients (Table III). The Cox's analysis demonstrated that the cytoEGFR protein level is an independent prognostic biomarker for the overall survival of OSCC patients ( $\mathrm{RR}=3.0 ; \mathrm{P}=0.035$ ) (Fig. 2; Table II), while the membEGFR level has no significant influence on survival in the same OSCC cohort (Table II).

Interestingly, in multivariate Cox's proportional hazard regression analysis $(\mathrm{RR}=2.57 ; \mathrm{P}=0.13)$ we found that even a slight increase of cytoEGFR protein level was associated with a higher risk of disease relapse. Again, membEGFR did not correlate with the probability of relapse in this cohort of OSCC patients (Table II).

Correlation of membranous EGFR and cytoplasmatic EGFR with other parameters. In bivariate two-sided Spearman correlation analysis, we calculated a significant correlation between membEGFR level and cytoEGFR level (correlation coefficient: $0.57 ; \mathrm{P}<0.001)$. No correlation was observed between the membEGFR level or cy toEGFR level and T-stage, $\mathrm{N}$-stage, grading, sex and age of the patients (Table I). 
Table I. Clinicopathological data of patients with oral squamous cell carcinoma.

\begin{tabular}{|c|c|c|c|c|c|c|c|}
\hline \multirow[b]{2}{*}{ Category } & \multirow[b]{2}{*}{$\begin{array}{c}\text { Number of } \\
\text { cases }\end{array}$} & \multicolumn{2}{|c|}{ membEGFR protein level } & \multirow[b]{2}{*}{ P-value } & \multicolumn{2}{|c|}{ cytoEGFR protein level } & \multirow[b]{2}{*}{ P-value } \\
\hline & & $\begin{array}{l}\text { Negative } \\
\text { (IRS0-2), } \mathrm{n}\end{array}$ & $\begin{array}{c}\text { Positive } \\
\text { (IRS3-12), n }\end{array}$ & & $\begin{array}{l}\text { Negative } \\
\text { (IRS0-2), } \mathrm{n}\end{array}$ & $\begin{array}{c}\text { Positive } \\
\text { (IRS3-12), n }\end{array}$ & \\
\hline Total & 45 & 36 & 9 & & 20 & 25 & \\
\hline \multicolumn{8}{|l|}{ Sex } \\
\hline Male & 31 & 24 & 7 & & 13 & 18 & \\
\hline Female & 14 & 12 & 2 & 0.524 & 7 & 7 & 0.618 \\
\hline \multicolumn{8}{|c|}{ Age, years } \\
\hline$<50$ & 11 & 10 & 1 & & 6 & 5 & \\
\hline$\geq 50$ & 34 & 26 & 8 & 0.303 & 14 & 20 & 0.443 \\
\hline \multicolumn{8}{|l|}{ T-stage } \\
\hline $\mathrm{I}$ & 6 & 5 & 1 & & 2 & 4 & \\
\hline II & 17 & 13 & 4 & & 9 & 8 & \\
\hline III & 11 & 9 & 2 & & 2 & 9 & \\
\hline IV & 11 & 9 & 2 & 0.870 & 7 & 4 & 0.633 \\
\hline \multicolumn{8}{|l|}{$\mathrm{N}$-stage } \\
\hline No & 19 & 14 & 5 & & 10 & 9 & \\
\hline $\mathrm{N} 1-3$ & 26 & 22 & 4 & 0.371 & 10 & 16 & 0.350 \\
\hline \multicolumn{8}{|l|}{ Grading } \\
\hline 1 & 3 & 2 & 1 & & 3 & 0 & \\
\hline 2 & 18 & 16 & 2 & & 9 & 9 & \\
\hline 3 & 24 & 18 & 6 & 0.501 & 8 & 16 & 0.058 \\
\hline
\end{tabular}

P-values were calculated using a Kruskal Wallis test. cyto, cytoplasmatic; EGFR, epidermal growth factor-receptor; memb, membranous; IRS, immunoreactive score.

\section{Discussion}

In this immunohistochemical analysis, we could show that a cytoEGFR localization is an independent prognostic marker for overall survival (OS) in a cohort of 45 OSCC patients $(\mathrm{RR}=3.0, \mathrm{P}=0.035)$. Moreover, the cytoEGFR was detectable in $56 \%$ of all cases, whereas high membEGFR level was detectable in only $20 \%$ of all cases. No evidence of nuclear localized EGFR was found in our cohort.

The prognostic effect of subcellular localization of EGFR protein (membranous/cytoplasmatic/nuclear) on overall and disease free survival (DFS) is assessed heterogeneously in the literature. Bossi et al (6) examined the prognostic effects of EGFR IHC data extracted from nine articles dealing with OSCC patients data. While three of these studies found a positive association of EGFR expression on survival (OS or DFS) of OSCC patients, no such correlation was found in the six other studies (6).

It is noteworthy that even a loss of EGFR expression may be related to invasiveness and epithelial-mesenchymal transition in oral squamous cell carcinoma (18). This could be explained by the observation that the detection of a receptor not always correlates with the activity of the induced pathway, but to the opposite. Therefore it might be possible that the tumorous EGFR-protein level is very low, but the signaling pathway is highly activated. This is what we found in a cohort of STS patients, where EGFR levels were low but pAKT S473 protein levels were elevated $(19,20)$. An explanation for such a situation could be that the interaction of high levels of EGFR ligands (e.g. EGF) can lead to a higher turnover of EGFR proteins. This ligand-receptor complex is normally internalized into the cytoplasm and only $50 \%$ of the internalized EGFR is recycled and transported back to the cell surface. When this cycle starts again, the level of membranous EGFR decreases and the level of cytoplasmic EGFR increases.

However, at the end of such a strongly induced EGFR-pathway the EGFR protein is no longer detectable, although the pathway is highly active (13). This indicates that very low levels of EGFR protein might have two opposite reasons i) very low expression of EGFR or II) a very high active EGFR-pathway associated with high level of internalization and degradation of the receptor.

Therefore point II) could be one reason why patients without detectable EGFR levels in their tumors could benefit from EGFR- specific therapies. The EGFR level could be low, because the turnover and the activity of the EGFR-pathway is very high. It is also possible, that high levels of HER 2 binds activated EGFR, forms a heterodimer and the internalization of this complex caused a reduced level of EGFR (21). In particular, the endocytosis, traffic, recycling and the degradation of EGFR is very complex and influenced by various 
Table II. Survival data of patients $(n=45)$ with oral squamous cell carcinoma.

\begin{tabular}{|c|c|c|c|c|c|c|c|c|}
\hline \multirow[b]{2}{*}{ Category } & \multicolumn{2}{|c|}{$\begin{array}{l}\text { membEGFR } \\
\text { protein level }\end{array}$} & \multirow[b]{2}{*}{ P-value } & \multirow[b]{2}{*}{$\mathrm{CI}$} & \multicolumn{2}{|c|}{$\begin{array}{l}\text { cytoEGFR } \\
\text { protein level }\end{array}$} & \multirow[b]{2}{*}{ P-value } & \multirow[b]{2}{*}{$\mathrm{CI}$} \\
\hline & $\begin{array}{l}\text { Negative } \\
\text { (IRSO-2) }\end{array}$ & $\begin{array}{l}\text { Positive } \\
\text { (IRS3-12) }\end{array}$ & & & $\begin{array}{l}\text { Negative } \\
\text { (IRS0-2) }\end{array}$ & $\begin{array}{l}\text { Positive } \\
\text { (IRS3-12) }\end{array}$ & & \\
\hline Total, $\mathrm{n}$ & 36 & 9 & & & 20 & 25 & & \\
\hline \multicolumn{9}{|l|}{ Kaplan-Meier analysis } \\
\hline Mean survival time, months & $33.2 \pm 7.6$ & $30.9 \pm 17.7$ & $\begin{array}{c}0.971 \\
\text { (log-rank) }\end{array}$ & & $40.2 \pm 10.0$ & $26.7 \pm 9.2$ & $\begin{array}{c}0.031 \\
\text { (log-rank) }\end{array}$ & \\
\hline \multicolumn{9}{|l|}{ Overall survival } \\
\hline Univariate Cox & Ref. & $\mathrm{RR}=1.02$ & 0.972 & $0.39-2.7$ & Ref. & $\mathrm{RR}=2.31$ & 0.039 & $1.04-5.1$ \\
\hline Multivariate Cox & Ref. & $\mathrm{RR}=1.31$ & 0.61 & $0.47-3.6$ & Ref. & $\mathrm{RR}=3.03$ & 0.035 & $1.08-8.5$ \\
\hline \multicolumn{9}{|l|}{ Relapse-free survival } \\
\hline Univariate Cox & Ref. & $\mathrm{RR}=1.17$ & 0.78 & $0.39-3.5$ & Ref. & $\mathrm{RR}=1.55$ & 0.33 & $0.64-3.8$ \\
\hline Multivariate Cox & Ref. & $\mathrm{RR}=1.53$ & 0.49 & $0.46-5.1$ & Ref. & $\mathrm{RR}=2.57$ & 0.13 & $0.76-8.6$ \\
\hline
\end{tabular}

cyto, cytoplasmatic; EGFR, epidermal growth factor-receptor; memb, membranous; CI, confidence interval; Ref., reference.
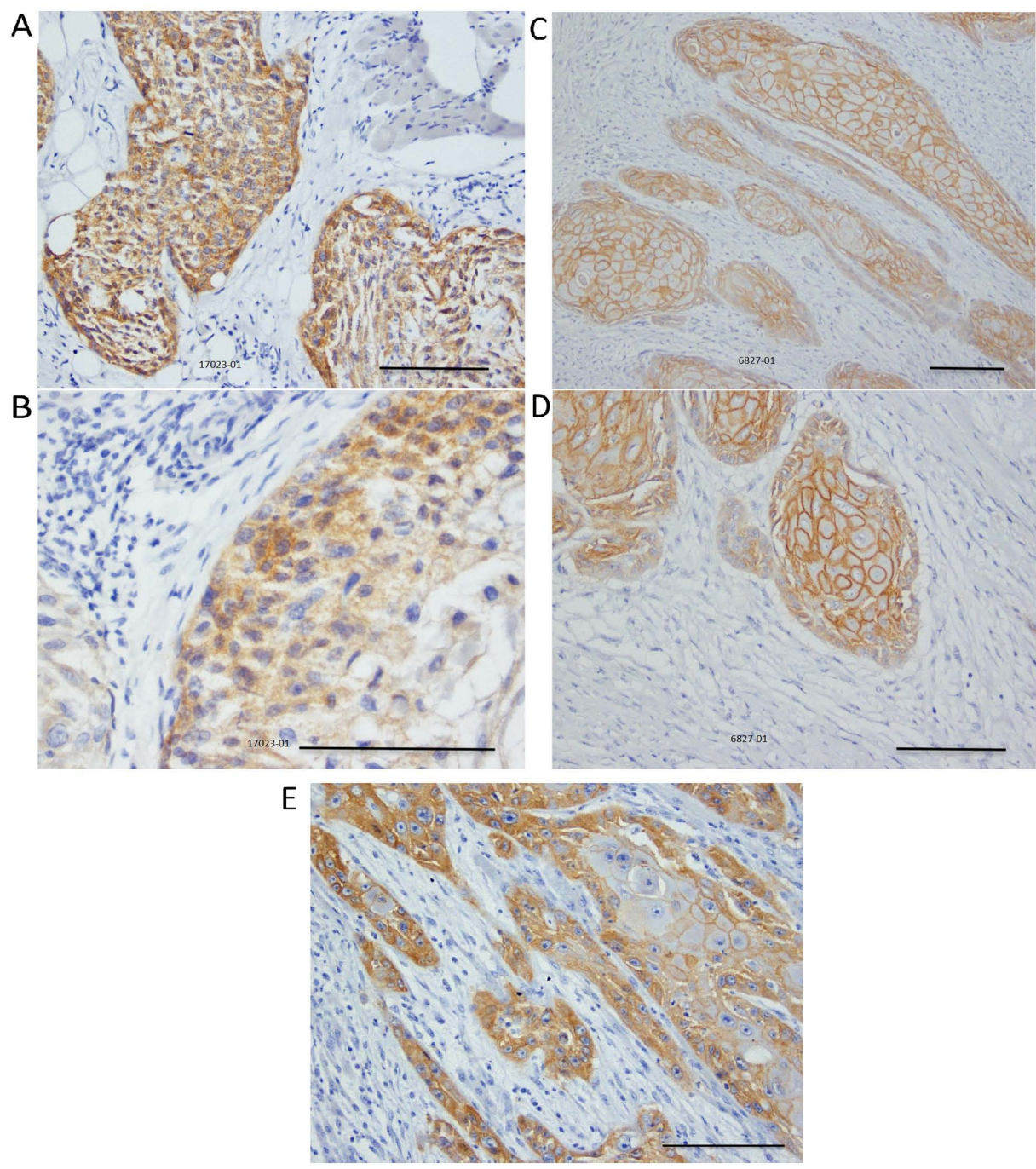

Figure 1. Examples of EGFR-specific staining of OSCC tumor samples. (A and B) Tumor slides positively stained for cytoEGFR. (C and D) Tumor slides positively stained for membEGFR. The preview of the figures can be seen in the top row and the enlargement of the same figure is presented below. (E) Tumor slide with both cytoEGFR and membEGFR levels in the same tumor. Scale bars, $100 \mu \mathrm{m}$. cyto, cytoplasmatic; EGFR, epidermal growth factor-receptor; memb, membranous; OSCC, oral squamous cell carcinoma. 
Table III. Clinicopathological data of patients with oral squamous cell carcinoma.

\begin{tabular}{|c|c|c|c|c|c|}
\hline \multirow[b]{2}{*}{ Category } & \multirow[b]{2}{*}{ Number of cases } & \multicolumn{2}{|c|}{ Univariate Cox analysis } & \multicolumn{2}{|c|}{ Multivariate Cox analysis } \\
\hline & & RR & P-value & RR & P-value \\
\hline Total & 45 & & & & \\
\hline \multicolumn{6}{|l|}{ Sex } \\
\hline Male & 31 & Ref. & & Ref. & \\
\hline Female & 14 & 0.63 & 0.30 & 0.61 & 0.32 \\
\hline \multicolumn{6}{|l|}{ Age, years } \\
\hline$<50$ & 11 & Ref. & & Ref. & \\
\hline$\geq 50$ & 34 & 2.35 & 0.09 & 4.55 & 0.01 \\
\hline \multicolumn{6}{|l|}{ T-stage } \\
\hline I & 6 & Ref. & & Ref. & \\
\hline II & 17 & 0.48 & 0.23 & 0.18 & 0.12 \\
\hline III & 11 & 0.64 & 0.47 & 0.25 & 0.05 \\
\hline IV & 11 & 1.05 & 0.93 & 0.36 & 0.12 \\
\hline \multicolumn{6}{|l|}{$\mathrm{N}$-stage } \\
\hline No & 19 & Ref. & & Ref. & \\
\hline $\mathrm{N} 1-3$ & 26 & 3.16 & 0.01 & 3.09 & 0.02 \\
\hline \multicolumn{6}{|l|}{ Grading } \\
\hline 1 & 3 & Ref. & & Ref. & \\
\hline 2 & 18 & 0.52 & 0.41 & 0.61 & 0.55 \\
\hline 3 & 24 & 1.10 & 0.90 & 1.75 & 0.49 \\
\hline
\end{tabular}

P-values were calculated using Cox regression analysis. RR, relative risk.

parameters and this could be important for therapeutic options (21).

Therefore, it is difficult to derive reliable prognostic information only from the EGFR content in the tumor, as has been done in some studies in OSCC patients.

For example, Ryott et al (22) (investigated 78 OSCC), Diniz-Freitas et al (23) (investigated 44 OSCC), Christensen et al (5) (investigated 192 OSCC) and Shah et al (24) (investigated 89 OSCC) but found no prognostic effects of EGFR protein levels. However, an indication of the activity of the EGFR pathway could be a better prognostic marker (which could be the level of pAKT473 protein) or the level of internalization of EGFR. The internalization could be estimated from the level of membranous vs. cytoplasmatic EGFR.

This is possible because Monteiro et al (25) published the prognostic effect of the combination of membEGFR and cytoEGFR protein level on OS in a cohort of 67 OSCC $(\mathrm{R}=4.92, \mathrm{P}=0.039)$. Nevertheless, this study does not assess the different prognostic effects of membEGFR compared to cytoEGFR protein levels. In a multivariate Cox's regression analysis, Huang and colleagues described a prognostic effect of membEGFR for 160 OSCC (OS HR: 1.775 (95\% CI, 1.136-2.772) (26), whereby the cytoEGFR protein level was not examined. In another cohort of 100 OSCC, only membEGFR was found to have a significant prognostic effect $(\mathrm{P}=0.02)$. The authors could not demonstrate such a correlation for the combination of membEGFR and/or cytoEGFR protein level (27).
In Fig. 1E, it is shown that the membEGFR and cytoEGFR could be found simultaneously in different regions of the same tumor. Here membEGFR is localised in the center whereas cytoEGFR is localised at the periphery of the tumor bulk. Such a picture can be explained by a higher content of functional EGFR ligand in the periphery, which is able to bind the receptor (followed by internalization and activation of the pathway). While lower ligand levels in the center of the tumor are unable to activate EGFR and, therefore, the level of membEGFR is high and the level of cytoEGFR is low. Our interpretation of higher cytoEGFR levels is that an activated EGF-receptor is more likely to be internalized and thus a higher proportion of cytoEGFR could represent a more activate EGFR pathway.

Taguchi (11) focused on a study of nuclear EGFR in a cohort of 82 OSCC patients. The authors found a positive staining reaction for nuclear EGFR in $28 \%$ of the tumor samples, but no significant correlation with patient survival. The nuclear localization of EGFR is of great interest, e.g. Yang et al (28) found that nuclear EGFR protein level was a better prognostic factor than the cytoplasmic EGFR level in rectal cancer patients.

In our opinion, it is important to consider the different localization of biomarkers, since the known biological properties of these markers highly depend on the different cell compartments. It was shown that the membEGFR can be internalized in a ligand dependent manner (29), while internalized cytoEGFR could be partially recycled and return 

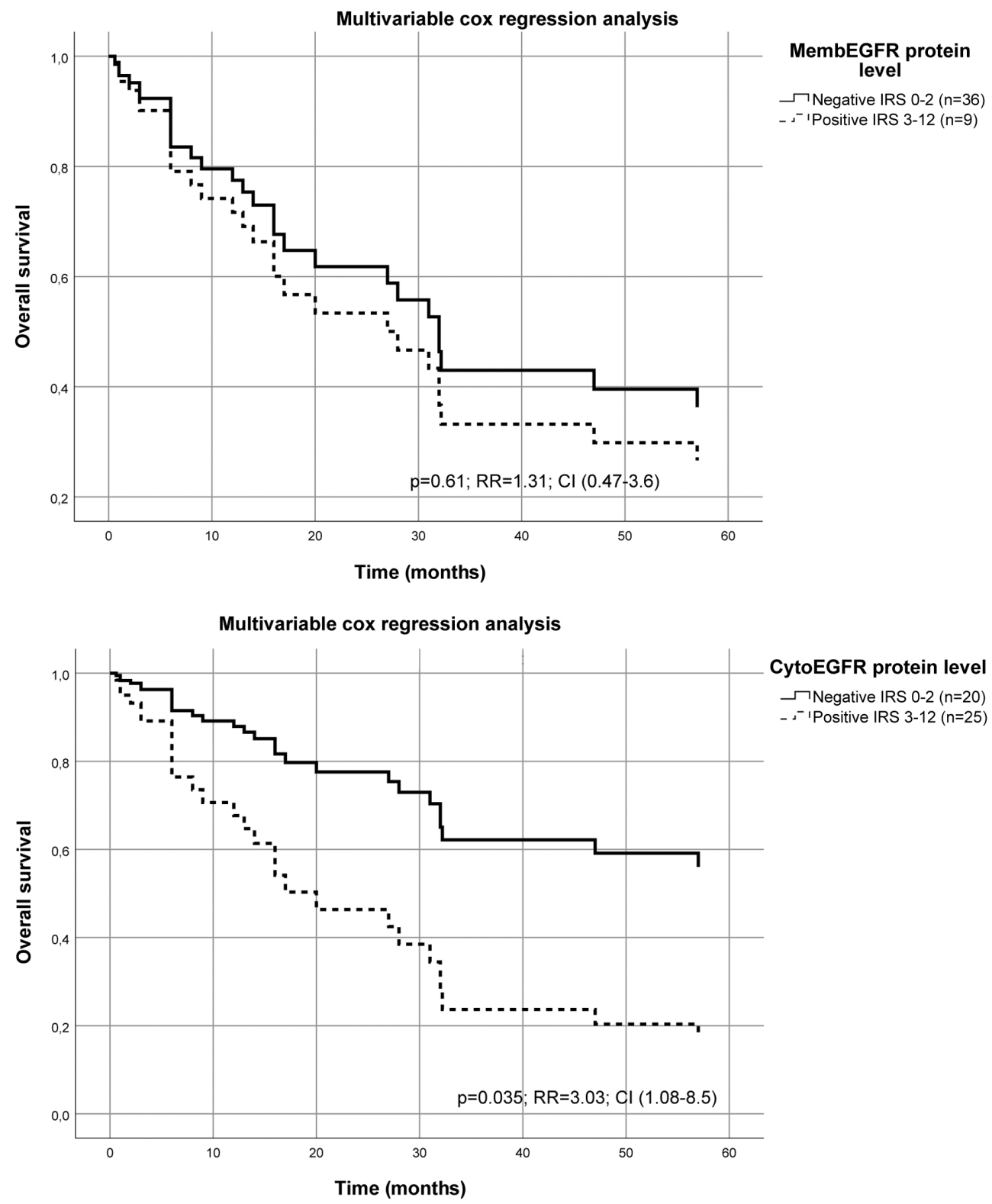

Figure 2. Multivariate Cox's hazard regression model for cytoplasmatic EGFR protein level or membranous EGFR protein level and survival in patients with OSCC. The protein expression levels of cytoEGFR or membEGFR for 45 patients with OSCC were associated with survival. The model was adjusted for tumor stage, $n$-stage and grading of the tumor, as well the age and sex of the patients. The relative risk of death was significantly increased for patients with a higher cytoEGFR protein level calculated using a multivariate Cox's hazard regression model $(\mathrm{P}=0.035 ; \mathrm{RR}=3.03 ; \mathrm{CI}, 1.08-8.5)$. For membEGFR the calculated multivariate Cox's hazard regression model missed the significant level $(\mathrm{P}=0.61 ; \mathrm{RR}=1.31 ; \mathrm{CI}, 0.47-3.6)$. The immunohistochemical staining was analyzed using the IRS of Remmele and Stegner (17) described in detail (15). CI, confidence interval; RR, relative risk; cyto, cytoplasmatic; EGFR, epidermal growth factor-receptor; memb, membranous; OSCC, oral squamous cell carcinoma; IRS, immunoreactive score.

to the cell surface. There is evidence that some cytoEGFR molecules can be translocated into the nucleus of tumor cells $(9,29)$. In addition, different isoforms of EGFR could even have different targets/induce different pathways which could have different biological and therapeutic effects $(13,19)$.

Nuclear EGFR functioned as a transcription factor and induced proliferation-associated genes and increase the chemo- and radioresistance of tumor cells (3). The therapeutic options should take into account the different turnover and traffic of such a receptor $(21,30)$.

In conclusion, this study shows that EGFR located in the cytoplasm is an independent prognostic biomarker of OSCC overall survival that may be important for individualized therapeutic approaches.

\section{Acknowledgements}

The authors would like to thank Dr Marcus Bauer (Institute of Pathology, Halle, Germany) for the technical support concerning the photodocumentation of the histological slides.

\section{Funding}

No funding was received.

\section{Availability of data and materials}

All data generated or analyzed during this study are included in this published article. 


\section{Authors' contributions}

KD, MK and AWE contributed to conception, design, data collection and manuscript writing. MS performed IHC analysis and interpretation of data. CW and DB supervised, received the ethics vote, reevaluated the IHC results and drafted the manuscript. Furthermore, DB was involved in the acquisition of data and the analysis of these data. WR and SR were involved in the data collection, and revised and drafted the manuscript. BAN supervised, funded the work, was involved in drafting the manuscript, and made substantial contributions to conception and gave final approval of the version to be published. All authors read and approved the final manuscript.

\section{Ethics approval and consent to participate}

The study was approved by the Ethics Committee of the Medical Faculty of the University Halle (ethic number 2017-81 issued on June 27, 2017). All procedures were in accordance with the Declaration of Helsinki. All patients provided written consent.

\section{Patient consent for publication}

Not applicable.

\section{Competing interests}

The authors declare that they have no competing interests.

\section{References}

1. Ferlay J, Soerjomataram I, Dikshit R, Eser S, Mathers C, Rebelo M, Parkin DM, Forman D and Bray F: Cancer incidence and mortality worldwide: Sources, methods and major patterns in GLOBOCAN 2012. Int J Cancer 136: E359-E386, 2015.

2. Eckert AW, Wickenhauser C, Salins PC, Kappler M, Bukur J and Seliger B: Clinical relevance of the tumor microenvironment and immune escape of oral squamous cell carcinoma. J Transl Med 14: 85, 2016.

3. Lo HW and Hung MC: Nuclear EGFR signalling network in cancers: Linking EGFR pathway to cell cycle progression, nitric oxide pathway and patient survival. Br J Cancer 94: 184-188, 2006.

4. Yarden Y: Grundlagen der Signaltransduktion. Onkologie 28 (Suppl 4): S14-S17, 2005 (In German).

5. Christensen A, Kiss K, Lelkaitis G, Juhl K, Persson M, Charabi BW, Mortensen J, Forman JL, Sørensen AL, Jensen DH, et al: Urokinase-type plasminogen activator receptor (uPAR), tissue factor (TF) and epidermal growth factor receptor (EGFR): Tumor expression patterns and prognostic value in oral cancer. BMC Cancer 17: 572, 2017.

6. Bossi P, Resteghini C, Paielli N, Licitra L, Pilotti S and Perrone F: Prognostic and predictive value of EGFR in head and neck squamous cell carcinoma. Oncotarget 7: 74362-74379, 2016.

7. Søland TM and Brusevold IJ: Prognostic molecular markers in cancer-quo vadis? Histopathology 63: 297-308, 2013.

8. Lo HW, Hsu SC, Ali-Seyed M, Gunduz M, Xia W, Wei Y, Bartholomeusz G, Shih JY and Hung MC: Nuclear interaction of EGFR and STAT3 in the activation of the iNOS/NO pathway. Cancer Cell 7: 575-589, 2005.

9. Marti U, Burwen SJ, Wells A, Barker ME, Huling S, Feren AM and Jones AL: Localization of epidermal growth factor receptor in hepatocyte nuclei. Hepatology 13: 15-20, 1991.

10. Lo HW, Xia W, Wei Y, Ali-Seyed M, Huang SF and Hung MC: Novel prognostic value of nuclear epidermal growth factor receptor in breast cancer. Cancer Res 65: 338-348, 2005.

11. Taguchi T: Nuclear translocation of epidermal growth factor receptor and its relation to clinicopathological factors in oral squamous cell carcinomas. Kokubyo Gakkai Zasshi 81: 45-52, 2014 (In Japanese).
12. Maramotti S, Paci M, Manzotti G, Rapicetta C, Gugnoni M, Galeone C, Cesario A and Lococo F: Soluble epidermal growth factor receptors (sEGFRs) in cancer: Biological aspects and clinical relevance. Int J Mol Sci 17: 593, 2016.

13. Weinholdt C, Wichmann H, Kotrba J, Ardell DH, Kappler M, Eckert AW, Vordermark D and Grosse I: Prediction of regulatory targets of alternative isoforms of the epidermal growth factor receptor in a glioblastoma cell line. BMC Bioinformatics 20: 434, 2019.

14. Eckert AW, Lautner MH, Schütze A, Taubert H, Schubert J and Bilkenroth U: Coexpression of hypoxia-inducible factor-1 $\alpha$ and glucose transporter-1 is associated with poor prognosis in oral squamous cell carcinoma patients. Histopathology 58: 1136-1147, 2011.

15. Eckert AW, Schutze A, Lautner MH, Taubert H, Schubert J and Bilkenroth U: HIF-1alpha is a prognostic marker in oral squamous cell carcinomas. Int J Biol Markers 25: 87-92, 2010.

16. Wichmann H, Güttler A, Bache M, Taubert H, Rot S, Kessler J, Eckert AW, Kappler M and Vordermark D: Targeting of EGFR and HER2 with therapeutic antibodies and siRNA: A comparative study in glioblastoma cells. Strahlenther Onkol 191: 180-191, 2015.

17. Remmele W and Stegner HE: Vorschlag zur einheitlichen definition eines immunreaktiven score (IRS) für den immunhistochemischen ostrogenrezeptor-nachweis (ER-ICA) im mammakarzinomgewebe. Pathologe 8: 138-140, 1987.

18. Kimura I, Kitahara H, Ooi K, Kato K, Noguchi N, Yoshizawa K, Nakamura $\mathrm{H}$ and Kawashiri S: Loss of epidermal growth factor receptor expression in oral squamous cell carcinoma is associated with invasiveness and epithelial-mesenchymal transition. Oncol Lett 11: 201-207, 2016.

19. Rot S, Taubert H, Bache M, Greither T, Würl P, Holzhausen HJ, Eckert AW, Vordermark D and Kappler M: Low HIF-1 $\alpha$ and low EGFR mRNA expression significantly associate with poor survival in soft tissue sarcoma patients; the proteins react differently. Int J Mol Sci 19: 3842, 2018.

20. Greither T, Koser F, Holzhausen HJ, Güttler A, Würl P, Kappler M, Wach S and Taubert H: MiR-155-5p and MiR-203a-3p are prognostic factors in soft tissue sarcoma. Cancers (Basel) 12: 2254, 2020.

21. Sigismund S, Avanzato D and Lanzetti L: Emerging functions of the EGFR in cancer. Mol Oncol 12: 3-20, 2018.

22. Ryott M, Wangsa D, Heselmeyer-Haddad K, Lindholm J, Elmberger G, Auer G, Avall Lundqvist E, Ried T and Munck-Wikland E: EGFR protein overexpression and gene copy number increases in oral tongue squamous cell carcinoma. Eur J Cancer 45: 1700-1708, 2009.

23. Diniz-Freitas M, García-Caballero T, Antúnez-López J, Gándara-Rey JM and García-García A: Pharmacodiagnostic evaluation of EGFR expression in oral squamous cell carcinoma. Oral Dis 13: 285-290, 2007.

24. Shah NG, Trivedi TI, Tankshali RA, Goswami JV, Jetly DH, Shukla SN, Shah PM and Verma RJ: Prognostic significance of molecular markers in oral squamous cell carcinoma: A multivariate analysis. Head Neck 31: 1544-1556, 2009.

25. Monteiro LS, Diniz-Freitas M, Garcia-Caballero T, Warnakulasuriya S, Forteza J and Fraga M: Combined cytoplasmic and membranous EGFR and p53 overexpression is a poor prognostic marker in early stage oral squamous cell carcinoma. J Oral Pathol Med 41: 559-567, 2012.

26. Huang SF, Cheng SD, Chien HT, Liao CT, Chen IH, Wang HM, Chuang WY, Wang CY and Hsieh LL: Relationship between epidermal growth factor receptor gene copy number and protein expression in oral cavity squamous cell carcinoma. Oral Oncol 48: 67-72, 2012

27. Maiorano E, Favia G, Maisonneuve P and Viale G: Prognostic implications of epidermal growth factor receptor immunoreactivity in squamous cell carcinoma of the oral mucosa. J Pathol 185: 167-174, 1998

28. Yang CC, Lin LC, Lin YW, Tian YF, Lin CY, Sheu MJ, Li CF and Tai MH: Higher nuclear EGFR expression is a better predictor of survival in rectal cancer patients following neoadjuvant chemoradiotherapy than cytoplasmic EGFR expression. Oncol Lett 17: 1551-1558, 2019.

29. Lo HW, Hsu SC and Hung MC: EGFR signaling pathway in breast cancers: From traditional signal transduction to direct nuclear translocalization. Breast Cancer Res Treat 95: 211-218, 2006.

30. Takei J, Kaneko MK, Ohishi T, Kawada M, Harada H and Kato Y: A novel anti-EGFR monoclonal antibody (EMab-17) exerts antitumor activity against oral squamous cell carcinomas via antibody-dependent cellular cytotoxicity and complement-dependent cytotoxicity. Oncol Lett 19: 2809-2816, 2020.

This work is licensed under a Creative Commons Attribution-NonCommercial-NoDerivatives 4.0 International (CC BY-NC-ND 4.0) License. 